\section{Economic Impact of a Potential Expansion of Pest Infestation: Apple Maggot in Washington State}

\author{
Suzette P. Galinato ${ }^{1}$, R. Karina Gallardo ${ }^{2,5}$, David M. Granatstein ${ }^{3}$, \\ and Mike Willett ${ }^{4}$
}

AdDitional InDEx wORDs. codling moth, Cydia pomonella, Malus domestica, Rbagoletis pomonella, spinosad

Summary. Apple maggot (Rbagoletis pomonella) is an insect pest of apple (Malus domestica) that is currently limited in extent in the commercial production areas of Washington State thanks to a quarantine program. We estimate the costs to the Washington economy if this pest were to spread more widely. Apple maggot control costs are related to the pressure of codling moth (Cydia pomonella), the most prevalent insect pest in commercial apple production in Washington State. It was found that the losses for the Washington apple industry's range from \$510 million to $\$ 557$ million, depending on the codling moth pressure. Our findings underscore the importance of an efficient quarantine program that minimized the risk of spreading the pest along with additional costs associated with quarantined areas.

A pple maggot is an insect pest with a wide host range and the potential to cause damage to about 55 plant species in 10 genera in the rose family (Rosaceae), including fruits such as apple, pear (Pyrus communis), and plum (Prunus domestica). Endemic to the eastern United States, apple maggot is widespread throughout the country, likely having been introduced to the Pacific northwestern United States, including Washington State, through the movement of infested apples (Sansford et al., 2016; Zhao et al., 2007). Fruit infested with apple maggot is unfit for human consumption, affecting marketing yields and, ultimately, profits.

Funding for this study was provided by the Washington Tree Fruit Research Commission Apple Crop Review.

We recognize the contributions of Jay Brunner, Michael Klaus, Brant Carman, Fred Scarlett, Jayme Smith, Jon DeVaney, and anonymous Washington State apple growers and packing house representatives.

${ }^{1}$ IMPACT Center, School of Economic Sciences, Washington State University, Hulbert Hall 101 , P.O. Box 646210, Pullman, WA 99164

${ }^{2}$ School of Economic Sciences, Puyallup Research and Extension Center, and Center for Precision and Agricultural Automated Systems, and IMPACT Center, 2606 E. Pioneer Avenue, Puyallup, WA 98371

${ }^{3}$ Center for Sustaining Agriculture and Natural Resources, Tree Fruit Research and Extension Center, Washington State University, 1100 N. Western Avenue, Wenatchee, WA 98801

${ }^{4}$ Washington Tree Fruit Research Commission, 1719 Springwater Avenue, Wenatchee, WA 98801

${ }^{5}$ Corresponding author. E-mail: karina_gallardo@ wsu.edu.

https://doi.org/10.21273/HORTTECH04141-18
In the commercial production regions in which apple maggot occurs, it is usually controlled with typical pesticide programs already applied to commercial apple orchards. Yield and quality losses for commercial apple operations are usually minimal, only increasing if pest management fails (Sansford et al., 2016). For example, insecticide applications during the summer to control for codling moth, the most prevalent insect pest in eastern Washington apple-production areas, have proven effective against apple maggot if applied at appropriate times (Brunner, 2018a, 2018b; Brunner and Klaus, $1993)$.

In Washington State, costs associated with apple maggot control include direct and indirect costs. Direct costs include additional pesticide applications and cold treatment $(40 \mathrm{~d}$ at $1{ }^{\circ} \mathrm{C}$ ) under controlled conditions. Cold treatment is only required for orchards located in apple maggotquarantine areas that ship fruit to specific export destinations (e.g., China and British Columbia, Canada). In this context, a quarantined area is any in which apple maggot is considered to be established (i.e., present, multiplying, and expected to continue) (Washington State Legislature, 2015). An indirect cost is the fruit price decline experienced after the additional storage period is imposed. Price decline is due to differences in apple inventories at harvest times. For example, early in the harvest season, when apple inventories are low, prices are higher than in the mid or late season, when inventories are high (Seetin, 2017).

The establishment of the apple maggot-quarantine area is part of a statewide strategy led by the Washington State Department of Agriculture (WSDA), which regulates or excludes apple maggot host material grown or originating in apple maggotinfested areas (Washington State Department of Agriculture, 2017) to reduce the spread of apple maggot. These regulations also facilitate the movement of commercial fruit to domestic and international markets by providing shippers with WSDA documentation certifying that their fruit is apple maggot free. In addition, the WSDA conducts a yearly apple maggot-surveillance program with three goals: 1) determine areas that meet the official "pest-free area" designation, 2) monitor commercial orchards to determine whether they meet regulations for shipping fresh apples out of the quarantined areas, and 3 ) implement the apple maggot response plan when apple maggot is detected in pest-free areas (Washington State Department of Agriculture, 2017).

Although the increased direct costs associated with field control of apple maggot do not represent a large increase beyond normal pesticide control costs in conventional orchards, meeting control needs associated with export regulations for fruit coming from quarantined areas could affect profits even further. In addition, pest expansion could negatively affect organic apple production, which makes up about $12 \%$ of Washington apple acres and has fewer allowable

\begin{tabular}{llll}
\hline $\begin{array}{l}\text { Units } \\
\text { To convert U.S. to SI, } \\
\text { multiply by }\end{array}$ & U.S. unit & SI unit & $\begin{array}{l}\text { To convert SI to U.S., } \\
\text { multiply by }\end{array}$ \\
\hline 0.4047 & $\mathrm{acre}(\mathrm{s})$ & $\mathrm{ha}$ & 2.4711 \\
45.3592 & $\mathrm{cwt}$ & $\mathrm{kg}$ & 0.0220 \\
$\left({ }^{\circ} \mathrm{F}-32\right) \div 1.8$ & ${ }^{\circ} \mathrm{F}$ & ${ }^{\circ} \mathrm{C}$ & $\left({ }^{\circ} \mathrm{C} \times 1.8\right)+32$
\end{tabular}


control options (Kirby and Granatstein, 2018). The risks of a potential increase in apple maggot infestation in quarantined areas could negatively affect the apple industry and the state's economy. The apple industry is of major economic importance to Washington State, representing the highest sales value of all crops. The state is the largest national producer (by volume and by value) of fresh apples, producing $65 \%$ of all fresh apples by volume and $73 \%$ of all fresh apples by value according to the U.S. Department of Agriculture (U.S. Department of Agriculture, 2017a) nationally. According to Globalwise, Inc. [Vancouver, WA (unpublished data)] and Belrose, Inc. [Pullman, WA (unpublished data)], the apple industry contributed an estimated $\$ 7.02$ billion in direct, indirect, and induced economic activity to the Washington State economy and directly employed 38,000 individuals.

In June 2015, the WSDA issued a special permit to a composting plant to haul municipal green waste from the Seattle metropolitan area (an apple maggot-quarantine area) to eastern Washington (an apple maggotfree area). Soon after, the industry's fears of potential apple maggot introduction were realized when apple maggot larvae were detected in an apple from one of the first loads of yard waste (Courtney, 2016). In response, the WSDA released an amendment to the apple maggotquarantine mandate, adding that municipal green waste could only be transported from an area under quarantine and disposed of at a solid waste landfill in a pest-free area (Washington State Legislature, 2015) under a special permit. Because green waste suppliers could not meet proposed permit conditions by Aug. 2015, all shipments of municipal green waste from the Seattle metropolitan area to apple maggot-free areas of eastern Washington were halted (Courtney, 2016). The WSDA commissioned a pest risk analysis (PRA) after this incident to investigate the risks of the municipal green waste movement practice. The study concluded that:

"The overall risk of entry of $\mathrm{R}$. pomonella on $M G W$ [municipal green waste] from the quarantined area to the PRA area is assessed as likely [emphasis original] to occur with low uncertainty... Introduction (entry and establishment) of $\mathrm{R}$. pomonella to the PRA area is likely to result in major economic impacts (with low uncertainty) resulting largely from the increased cost of control in commercial premises, particularly apple orchards, costs and losses related to the effects on export markets, as well as environmental impacts arising from increased pesticide use." (Sansford et al., 2016)

The PRA recommended that a heat treatment be applied to municipal green waste to guarantee the eradication of apple maggot pupae before transporting waste to apple maggot-free areas (Sansford et al., 2016).

Although the PRA was biologically comprehensive, it did not assess the economic impact of increasing the risk of apple maggot infestation and establishment in apple maggot-free areas on the apple industry or on the state economy. This study calculates the current direct, short-term costs associated with apple maggot in quarantined and nonquarantined areas for conventional and organic apple production. In addition, we estimate the indirect and induced costs of a potential apple maggot spread in nonquarantined areas on the Washington State economy.

A 1982 study estimated that Washington's commercial apple industry would incur additional spray costs and market opportunity losses of $\$ 25$ million per year if apple maggot infestation became widespread in the state's commercial apple-producing areas (Schotzko, 1982). Zhao et al. (2007) estimated that the industry would have experienced annual losses of $\$ 4$ to $\$ 8$ million from increased spray costs if apple maggot infestation had spread at its historic rates. They also analyzed the benefits of mitigating the spread of apple maggot and estimated that reducing the spread of apple maggot by $10 \%$ would result in benefits of \$1.52 million per year for the whole economy (including apple consumers and apple producers in Washington and in other parts of the United States). Compared with these previous studies, our study provides updated direct estimates of the potential losses to the apple industry and the Washington State economy from a potential increase in apple maggot-threatened and-quarantined areas. To determine price declines as harvest season progresses, we calculated the inverse elasticity of supply for each apple variety. We also used partial budget and economic impact analyses to calculate the profit losses from a potential expansion of apple maggot.

\section{Materials and methods}

First, to assess additional costs associated with a potential apple maggot infestation, we focused our analysis on four representative (based on market price) apple varieties: 'Red Delicious', representing low-value apples (Gallardo and Galinato, 2016); 'Fuji' and 'Gala', representing mid-value apples (Galinato and Gallardo, 2016; Galinato et al., 2016a), and 'Honeycrisp', representing high-value apples (Galinato and Gallardo, 2012). Also included are organic varieties 'Gala', 'Red Delicious', and 'Honeycrisp' (Galinato et al., 2016a, 2016b).

Second, we identified four scenarios according to apple maggot status: 1) threatened and quarantined, 2) threatened and nonquarantined, 3) nonthreatened and quarantined, and 4) nonthreatened and nonquarantined. Table 1 reports the commercial apple acreage in each scenario as of 2015 (Washington State Department of Agriculture, 2017). "Threatened" indicates that apple maggot has been detected within half a mile of the orchard boundary in the past 3 years (20122015). "Nonthreatened" means that apple maggot has not been detected within a half mile of the orchard boundaries in the past 3 years (2012-15). "Quarantined" refers to areas in which the pest is established ("established" means present in an area, multiplying, and expected to continue) (Washington State Legislature, 2015). Eighty-five percent of conventional and $97 \%$ of organic apple orchard acreage are located in nonthreatened and nonquarantined areas; $0.83 \%$ of conventional and $0.24 \%$ of organic orchard acreage are located in threatened and quarantined areas (Table 1). We classify areas by threat and quarantine status because the direct costs of apple maggot infestation will not be the same across the four scenarios. In this analysis, additional chemicals to control for apple maggot are applied only in threatened areas (Areas 1 and 2), 
whereas additional storage is required only for apples from quarantined areas (Areas 1 and 3 ).

Direct CONTROL COSTS FOR APPLE MAgGOT IN WASHINGTON State. These costs are represented by two categories: additional chemical costs, associated with threatened areas, and additional storage costs, associated with quarantined areas. We use Washington State University (WSU) apple enterprise budgets as a baseline to estimate direct costs for the seven apple varieties listed previously (Galinato et al., 2016a, 2016b, 2016c; Galinato and Gallardo, 2012; Gallardo and Galinato, 2016). Baseline costs included control costs (i.e., chemical sprays and application costs) for codling moth but not for apple maggot. We treat apple maggot control (chemical plus application costs) as an additional cost to growers. The apple maggot control strategy is associated with codling moth control strategy. The control window for apple maggot occurs between late June and late September and overlaps with the control window for second- and third-generation codling moth, when second and third generations occur (Brunner 2016, 2018a, 2018b; Brunner and Klaus, 1993). As codling moth pressure increases (i.e., second and third generations), growers spray more often to control for codling moth, so fewer sprays are necessary to control apple maggot. The additional costs of spraying for apple maggot should be low when codling moth pressure is high and high when codling moth pressure is low (Brunner, 2016, 2018a, 2018b; Brunner and Klaus, 1993). Because we cannot assert with certainty the type of codling moth pressure an orchard faces, we consider three management scenarios to control low, moderate, and high codling moth pressure. For each level, we estimate the cost (materials and application) for additional sprays to control apple maggot, data obtained from WSU crop protection guide (Washington State University, 2018).

Apple maggot control costs also vary depending on the apple variety because of different harvest dates and the different timing of the chemical applications. We estimate the chemical costs for early-season harvest variety 'Gala', midseason harvest varieties 'Red Delicious' and
'Honeycrisp', and late-season harvest variety 'Fuji'. Under high codling moth pressure, there are no costs associated with organic apples (regardless of variety) because we assume that growers will not produce organic apples if codling moth pest pressure is high.

Costs associated WITH APPLE MAGgOT-QUARANTINE AREAS. Export market destinations often require that the apples being shipped are grown in pest-free areas, and apple maggot is not the exception. If grown in a pest quarantine area, apples must pass a number of requirements to prevent pest spread in the importing country. For example, the Canadian province of British Columbia and China require additional storage of $40 \mathrm{~d}$ at $1{ }^{\circ} \mathrm{C}$ for apples coming from Washington apple maggot-quarantine areas. The additional storage implies additional costs of about $\$ 11$ per 850-lb bin (Galinato et al., 2016a, 2016b, 2016c; Galinato and Gallardo, 2012; Gallardo and Galinato, 2016; packing house representative, unpublished data). In this study, we only include the quarantine costs that represent an additional cost due exclusively to apple maggot. For instance, we do not consider Mexico, because this country requires cold storage for all Washington apples to control oriental fruit moth (Grapholita molesta), which Mexico considers established throughout Washington's apple-production area, regardless if produced in an apple maggot-free or -quarantine area. Therefore, the additional storage costs would not be exclusively attributed to apple maggot, as is the case for British Columbia, Canada, and China (Northwest Horticultural Council, 2018).

Additional storage period Costs. Besides the cost of regular cold storage, the additional days in storage cause a delay in delivering apples to market, which decreases the price received. The additional days in storage also cause a delay in exporting apples to British Columbia and China. We assume that if apples were not exported, importers would find other sources of apples (e.g., the European Union, Chile, New Zealand) or other products that might replace apples to maintain their customer base in those destinations. As a result, apples from Washington State will lose shelf space in these locations and apple exporters will lower their prices to entice importers to purchase Washington apples when they come out of storage (F. Scarlett, personal communication). We assume that the price of apples will decrease because of shipment delays; our estimation of the price decrease is discussed in more detail herein. The price decrease is built on the following assumptions: 1) apples produced in each area have a fixed destination, 2) a percentage is exported, and 3 ) the remaining percentage is destined to the domestic market. Our assumptions further imply no substitution between apples grown in quarantined and nonquarantined areas.

Apples that come out of storage will likely add to those quantities to be shipped in a given schedule (see shipment schedule in Table 2). For instance, 'Gala' quantities coming out of storage will be added to 'Gala' quantities scheduled for shipment in October, which means an excess in the total export supply of 'Gala' for that month. We estimate the inverse elasticity of apple supply by month for 'Gala', 'Red Delicious', and 'Fuji' to see how sensitive prices would be if there were an excess supply. The inverse elasticity of supply provides the percentage change in price given a $1 \%$ change in the quantity of fresh apple shipments (Nicholson and Snyder, 2010).

The inverse supply function is specified as price-dependent function of the quantity supplied. A regression model is estimated in the following form:

$$
\begin{aligned}
\operatorname{In}\left(P_{i t}\right)= & \alpha_{0}+\alpha_{1} \operatorname{In}\left(Q_{i t}\right)+\alpha_{2} P P I_{t} \\
& +\alpha_{3} S_{T O R_{t}+\delta_{k} M_{\text {ONTH }}} \\
& \times \operatorname{In}\left(Q_{i t}\right)+\varepsilon_{i t}
\end{aligned}
$$

where $i=$ apple variety 'Fuji', 'Gala', and 'Red Delicious'; $t=$ month of the year $($ year $=2011-16) ; P=$ price of apple variety $i ; Q=$ quantity of fresh shipments of an apple variety $i$ from Washington State; PPI = producer prices paid index for apple production; $S T O R=$ monthly federal funds effective rate as a measure of storage opportunity costs (Winfree et al., 2004); MONTH = dummy variable for a given month $k$ (i.e., September through July of a marketing year); and $\varepsilon=$ random error term. The 
interaction variables between MONTH and quantity of fresh shipments are included to capture the variation in the shipments throughout the marketing year.

The Washington State Tree Fruit Association (2016a) provided the monthly data for the prices and quantity of fresh shipments by apple variety. PPI data are obtained from the Quick Stats Database with the U.S. Department of Agriculture National Agriculture Statistics Service (U.S. Department of Agriculture, 2017b). Since the data represent prices paid by all agricultural farmers, the index is adjusted for apple production by selecting the input items or groups used by apple producers and aggregating these inputs to generate an apple PPI. The federal funds rates are obtained from the Board of Governors of the Federal Reserve System (2017).

An important issue in the aforementioned specification is the endogeneity of $Q_{i t}$. Endogeneity means there is a contemporaneous correlation between a regressor and disturbance in the model and it will render estimators that are inconsistent (Kennedy, 1998). Endogeneity in $Q_{i t}$ is tested and found using Durbin-Wu-Hausman test in Stata (StataCorp, 2017). To address the endogeneity of this regressor, we estimate the aforementioned model using an instrumental variable technique. The instrument should be associated with $Q_{i t}$ but not the disturbance term; it can be correlated with $P_{i t}$ but only through an indirect path, that is, the instrument only has the direct correlation with the regressor, $Q_{i t}$, which in turn determines $P_{i t}$. The instrumental variable comes from the following equation: $\ln \left(Q_{i t}\right)=\beta_{o}+\beta_{I}$ $\ln \left(P I V_{k t}\right)+\mu_{i t}$, where $P I V=$ price of a different apple variety $k$, and serves as an instrument for $Q_{i t}$. For 'Fuji' or 'Gala', the instrumental variable is the log of the price of 'Red Delicious'; for 'Red Delicious', the instrument variable is the $\log$ of the price of 'Fuji'. The Stock-Yogo test in Stata (StataCorp, 2017) is used to infer whether the instrumental variables are weak, and results rejected the null hypothesis of weak instruments at the $5 \%$ level of significance.

The coefficient estimate for the inverse elasticity of supply is derived by taking the sum of $\left(\hat{\alpha}_{1}+\hat{\delta}_{k}\right)$, where $k$ corresponds to a particular month. These elasticity estimates are $-1.04 \%$ in October for 'Gala', $-1.02 \%$ in November for 'Red Delicious', and $-1.81 \%$ in December for 'Fuji'. This should be interpreted, for instance, as a $1 \%$ increase in the quantity of fresh shipments of 'Gala' would lead to a decrease in price by $1.04 \%$ in October.

Price discounts are applied in the month in which the apples are shipped to the Canadian provinces of British Columbia and Alberta as well as to China. Exports to British Columbia, Alberta, and China represent $1.74 \%$ of total Washington 'Gala' apple exports [based on a 5-year average over the 2012-13 to 201516 marketing seasons (Washington State Tree Fruit Association, 2016b)]. We include Alberta with the destinations requiring cold storage to account for additional transportation

Table 1. Distribution in acreage and percentage of commercial conventional and organic apple cultivated surface according to apple maggot status, threaten, and quarantine in Washington State 2016 (Washington State Department of Agriculture, 2017).

\begin{tabular}{llrrrrr}
\hline \multirow{2}{*}{$\begin{array}{l}\text { Orchard threat } \\
\text { status }\end{array}$} & \multirow{2}{*}{$\begin{array}{c}\text { Quarantine } \\
\text { status }\end{array}$} & \multicolumn{2}{c}{ Conventional } & & \multicolumn{2}{c}{ Organic } \\
\cline { 7 - 8 } & & Acres & \% of total & & Acres & \% of total \\
\hline Threatened & Quarantined & 1,351 & $0.83 \%$ & & 42 & $0.24 \%$ \\
Threatened & Nonquarantined & 184 & $0.11 \%$ & & 0 & $0.00 \%$ \\
Nonthreatened & Quarantined & 23,224 & $14.21 \%$ & & 471 & $2.69 \%$ \\
Nonthreatened & Nonquarantined & 138,683 & $84.85 \%$ & & 17,007 & $97.08 \%$ \\
& Total & 163,442 & $100.00 \%$ & & 17,519 & $100.00 \%$ \\
\hline
\end{tabular}

${ }^{\mathrm{z}} 1$ acre $=0.4047$ ha.

Table 2. Harvest schedule, end of 40-d storage, and export shipment schedule of apple varieties 'Gala', 'Red Delicious', and 'Fuji'. Information used to estimate price variations resulting from requirements from selected export destinations of Washington State-grown apples coming from apple maggot-quarantine areas.

\begin{tabular}{lccc}
\hline Variety & $\begin{array}{c}\text { Harvest } \\
\text { schedule }\end{array}$ & $\begin{array}{c}\text { End of 40-d } \\
\text { storage }\end{array}$ & $\begin{array}{c}\text { Shipment } \\
\text { schedule }\end{array}$ \\
\hline Gala & 15 Aug. & 24 Sept. & October \\
Red Delicious & 15 Sept. & 15 Oct. & November \\
Fuji & 15 Oct. & 24 Nov. & December \\
\hline
\end{tabular}

Table 3. Percentage price reduction [5-year average (2011-12 to 2015-16 marketing seasons)] $40 \mathrm{~d}$ after harvest for apple varieties 'Red Delicious', 'Gala', and 'Fuji'. Information used to estimate price variations resulting from requirements from selected export destinations of Washington State-grown apples coming from apple maggot-quarantine areas.

\begin{tabular}{lcccc}
\hline \multicolumn{5}{c}{ Price reduction (\%) } \\
\hline $\begin{array}{l}\text { Red } \\
\text { Delicious }\end{array}$ & Gala & Fuji & $\begin{array}{c}\text { Organic Red } \\
\text { Delicious }\end{array}$ & $\begin{array}{c}\text { Organic } \\
\text { Gala }\end{array}$ \\
\hline 1.78 & 1.81 & 3.16 & $1.78^{\mathrm{z}}$ & 1.81 \\
\hline
\end{tabular}

${ }^{\mathrm{z}}$ Organic price reductions are assumed to be the same as those for the conventional variety. 
storage costs, and price discounts as described previously. We have also included the fee for apple pest certification on all apples produced in Washington State or marketed under Washington State grades and standards at the rate of $\$ 0.015 / \mathrm{cwt}$ (Washington State Legislature, 2018).

ECONOMIC IMPACT ANALYSIS Results: ApPle MAggot SPREAD COST FOR THE WASHINGTON ECONOMY. To estimate the economic impact of an increased risk of an expansion of apple maggot-threatened and -quarantined areas, we first calculate the economic contribution of the apple industry to the Washington economy using data from WSU enterprise budgets (Galinato et al., 2016a, 2016b, 2016c; Galinato and Gallardo, 2012; Gallardo and Galinato, 2016). To estimate the aggregate effects of losses in profit, we consider the acreage included in the four areas as reported in Table 1. For each area type, we assume the same variety mix acreage distribution as the Washington acreage distribution. We also use data from a Globalwise, Inc., and Belrose, Inc. (unpublished data) study as a basis for the economic contributions of the fresh apple packing and processing industries and the 2015 IMPLAN inputoutput (I/O) data for Washington State (IMPLAN, 2016). IMPLAN is a widely used methodology to calculate the economic impact of enterprises. It is based on an $\mathrm{I} / \mathrm{O}$ analysis that attempts to describe an array of transactions among different sectors in a defined industry for a given period (University of Wisconsin, 2018).

Second, we estimate the apple industry's contributions to the Washington economy under low, moderate, and high codling moth pressure. To estimate the economic contribution for 2017, we use the built-in gross domestic product deflator in IMPLAN for 2017. Third, we estimate the economic impacts of apple maggot further spreading to appleproduction areas. $\mathrm{I} / \mathrm{O}$ modeling is frequently used in economic impact analyses, including those related to agricultural commodities (e.g., Armah et al., 2016; Collart et al., 2015; Mon and Holland, 2006) and pest or disease (e.g., Evans et al., 2010; Pendell et al., 2007; Zapata et al., 2016). Because of the model's underlying assumptions, such as fixed proportion of inputs and lack of supply-side constraints (Bess and Ambargis, 2011; Zhao et al., 2006), results tend to be high but can be used as an upper-bound estimate of impacts (Hughes, 2003; Rose and Liao, 2005).

\section{Results and discussion}

Apple maggot control cost FOR INDIVIDUAL WASHINGTON APPLE OPERATIONS. We compare the profits of apple operations in the three apple maggot-affected areas (Table 1) with the best-case scenario (i.e., Area 4, neither threatened nor quarantined). Compared with moderate and high codling moth pressure, we observe higher profit losses as a result of potential apple maggot infestation for apple orchards under low codling moth pressure for both conventional and organic apples in apple maggotaffected Areas 1 and 2. This is mainly due to the higher costs incurred to control apple maggot under low codling moth pressure vs. under moderate and high pressure (Table 4 ). We observe higher profit losses for 'Fuji' compared with the other apple varieties included in this study when quarantined costs (storage cost and price decline) are considered (applies to Areas 1 and 3 , which would account for quarantine costs) because of its higher net yields relative to 'Red Delicious' and 'Gala', and when apple maggot control costs (additional chemical sprays) are included (applies to Areas 1 and 2, which would account

Table 4. Cost of additional chemicals and application for controlling apple maggot under different levels of codling moth pressure for apple varieties 'Red Delicious', 'Gala', 'Fuji', and 'Honeycrisp', grown under conventional and organic methods in Washington State.

\begin{tabular}{lccr}
\hline & \multicolumn{3}{c}{ Cost $(\$ / \text { acre })^{\mathrm{z}}$} \\
\cline { 2 - 4 } Variety & \multicolumn{3}{c}{ Codling moth pressure } \\
\cline { 2 - 4 } Red Delicious & $370.46^{\mathrm{y}}$ & Moderate & High \\
Gala & 257.50 & 199.91 & 0.00 \\
Fuji & 396.53 & 86.92 & 0.00 \\
Honeycrisp & 370.46 & 225.97 & 26.07 \\
Organic Red Delicious & 111.19 & 199.91 & 0.00 \\
Organic Gala & 111.19 & 11.19 & - \\
Organic Honeycrisp $^{\mathrm{x}}$ & 111.19 & 111.19 & - \\
\hline
\end{tabular}

${ }^{\mathrm{z}} \$ 1 /$ acre $=\$ 2.4711 / \mathrm{ha}$.

'Authors' estimates based on apple maggot pest-control strategies (Brunner, 2018a, 2018b; Brunner and Klaus, 1993).

${ }^{\mathrm{x}}$ All organic apples (both low and moderate codling moth pressure) get two applications of spinosad to control for potential apple maggot infestation. Both applications are applied on or before the first week of August. Spinosad has a 4 -h re-entry interval. for threatened costs) since 'Fuji' requires more chemical sprays for apple maggot compared with other apple varieties.

Profit losses for organic apples are the same under low and moderate levels of codling moth pressure because, in both cases, producer spray two applications of spinosad (Entrust; Dow AgroSciences, Indianapolis, IN) to control for potential apple maggot infestation. The detailed partial budgets are presented in Supplemental Tables $1-3$. Table 5 summarizes the partial budgets.

ECONOMIC CONTRIBUTIONS OF THE WASHINGTON APPLE INDUSTRY. The contributions of the Washington go beyond the $\$ 2$ billion value of fresh apple sales. We consider the three sectors of the apple industry: field-level apple production, fresh apple packing, and apple processing. Moreover, contributions include diindirect, and induced effects. include changes arising from interindustry transactions as supplying industries respond to the demand from the directly affected industry. Induced effects include those from tures made by employees of directly and indirectly affected industry sectors. IMPLAN reports on the employment, labor income, value added, and total output (IMPLAN, 2016). Table 6 shows the Washington apple industry to the state economy processing of apples. Indirect 
apple industry's estimated economic contributions. IMPLAN employment is the number of jobs-including fulltime, part-time, and temporary jobscreated in the apple industry.

Labor income includes employee compensation (i.e., wages, salaries, and benefits) and proprietor income (i.e., payments received by selfemployed individuals and unincorporated business owners, including capital consumption allowance, recorded on federal tax form 1040-C). Labor income contributed $\$ 3.27$ billion of personal income to the Washington economy under low codling moth pressure in the commercial apple orchards, $\$ 3.26$ billion under moderate codling moth pressure, and \$3.11 billion under high codling moth pressure (Table 6). The total value added is the sum of employee compensation, proprietor income, other propertytype income, and taxes. The apple industry added $\$ 4.58$ billion in value added contributions to the Washington economy under low codling moth pressure; $\$ 4.57$ billion under moderate pressure; and $\$ 4.39$ billion under high pressure.

We estimate the direct output values of the Washington apple industry to be $\$ 3.81$ billion to $\$ 3.95$ billion, depending on the level of pest pressure in the apple orchards. Because of interindustry linkages, the total economic contribution of the apple industry under, for example, moderate codling moth pressure is $\$ 9.48$ billion, comprising $42 \%$ direct output and $58 \%$ output from other sectors within the state (the sum of indirect and induced effects). The total output multiplier for the apple industry is about 2.40 (i.e., total effects divided by direct effects). This estimate indicates that for every $\$ 1$ of fresh apple packing and apple processing, about $\$ 2.40$ is generated in the state's economy, that is, for every apple industry dollar, an additional $\$ 0.67$ is generated in sectors providing inputs to the apple industry (indirect effects) and an additional \$0.73

Table 5. Annual profit loss for apple varieties 'Red Delicious', 'Gala', 'Fuji', and 'Honeycrisp' grown conventionally and organically. Profit loss calculated after additional apple maggot control costs under different assumed levels of codling moth (CM) pressure and for three distinctive areas according to apple maggot status in Washington State.

\begin{tabular}{|c|c|c|c|c|c|c|c|}
\hline \multirow[b]{3}{*}{ Variety } & \multicolumn{6}{|c|}{ Annual profit loss $(\$ / \text { acre })^{\mathrm{z}}$} & \multirow{3}{*}{$\begin{array}{c}\text { Nonthreatened, } \\
\text { quarantined } \\
\text { (Area 3) }\end{array}$} \\
\hline & \multicolumn{3}{|c|}{$\begin{array}{l}\text { Threatened, quarantined } \\
\text { (Area 1) }\end{array}$} & \multicolumn{3}{|c|}{$\begin{array}{l}\text { Threatened, nonquarantined } \\
\text { (Area 2) }\end{array}$} & \\
\hline & $\begin{array}{l}\text { Low } \\
\text { CM }\end{array}$ & $\begin{array}{c}\text { Moderate } \\
\text { CM }\end{array}$ & $\begin{array}{c}\text { High } \\
\text { CM }\end{array}$ & $\begin{array}{l}\text { Low } \\
\text { CM }\end{array}$ & $\begin{array}{l}\text { Moderate } \\
\text { CM }\end{array}$ & $\begin{array}{c}\text { High } \\
\text { CM }\end{array}$ & \\
\hline Red Delicious & -497 & -269 & -2 & -495 & -267 & 0 & -2 \\
\hline Gala & -370 & -127 & -3 & -367 & -124 & 0 & -3 \\
\hline Organic Red Delicious & -150 & -150 & & -149 & -149 & & -2 \\
\hline Organic Gala & -161 & -161 & & -158 & -158 & & -3 \\
\hline Organic Honeycrisp & & & & -171 & -171 & & \\
\hline
\end{tabular}

${ }^{\mathrm{z}} \$ 1 /$ acre $=\$ 2.4711 / \mathrm{ha}$

'Additional costs for variety 'Honeycrisp' are not included in the analysis for Areas 1 and 3 because this variety was not exported to British Columbia and China; hence, it is not necessary to include additional storage or price decline costs.

Table 6. Direct, indirect and induced contributions of the apple industry to the Washington State economy, 2017. Contributions are presented for three scenarios assuming three levels codling moth pressure, low, moderate, and high. ${ }^{\mathrm{z}}$

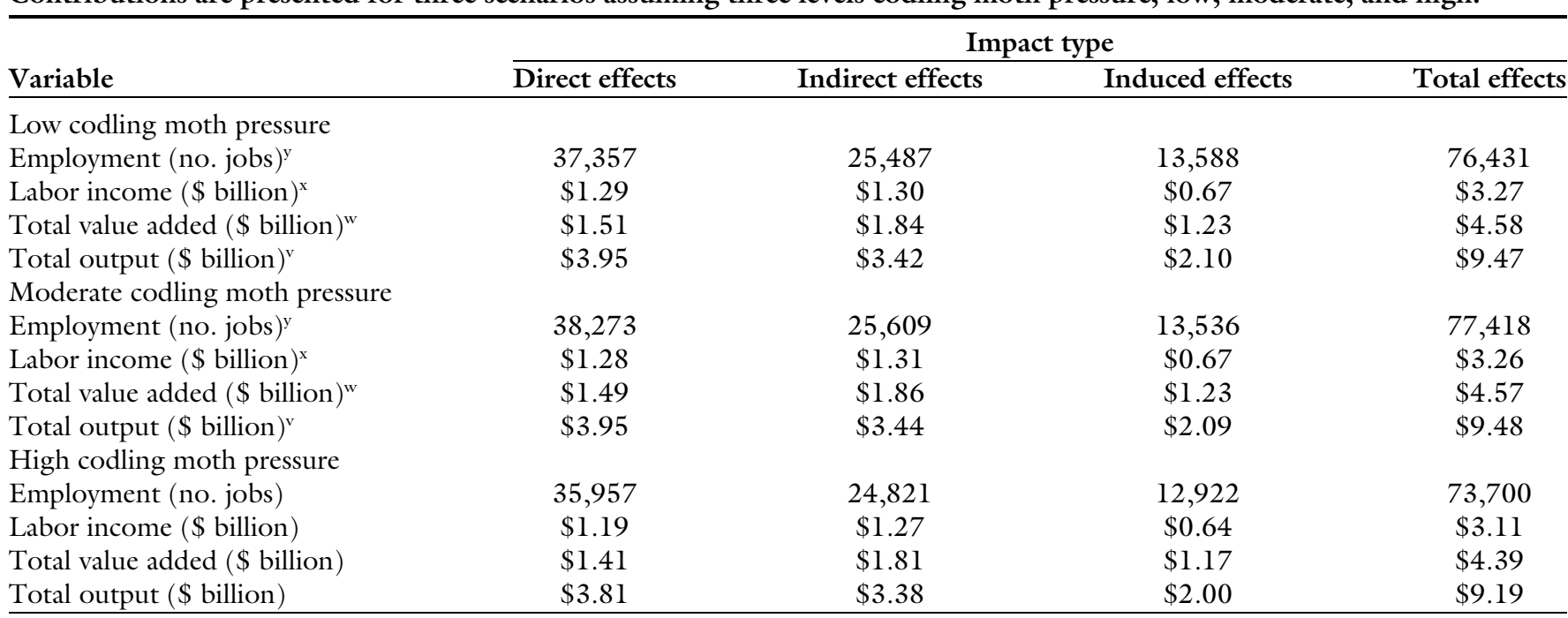

${ }^{\mathrm{z}}$ Sum of economic contributions by the apple farming, fresh apple packing, and processed apple-production sectors.

${ }^{\mathrm{y}}$ Labor income $=$ employee compensation + proprietor income.

${ }^{\mathrm{x}}$ Value added $=$ labor income + proprietor income + other property income + indirect business taxes.

${ }^{\mathrm{w}}$ Output $=$ intermediate expenditures + value added. 
is earned by businesses providing goods and services to employees of the apple industry and indirectly affected sectors (induced effects). The values reported in Table 6 align with the report from Globalwise, Inc. and Belrose, Inc. (unpublished data), which estimated $\$ 3.35$ billion in direct effects, $\$ 3.67$ billion in indirect and induced effects, and $\$ 7.03$ billion in total effects.

IMPACTS OF FURTHER APPLE MAGGOT INFESTATION ON THE WASHINGTON ECONOMY. We examine the economic impacts of a $100 \%$ loss of apple maggot-free areas (i.e., all apples are grown in apple maggotthreatened and -quarantined area) compared with the baseline situation. In this scenario, instead of only $0.8 \%$ of conventional and $0.2 \%$ of organic apple acreage (see Table $\mathrm{l}$ ) incurring additional chemical costs for apple maggot, storage costs, and price discounts, $100 \%$ of all apple acreage would incur these additional costs in addition to the apple pest certification fee.

Relative to current apple industry values (Table 7 ), a complete loss of apple maggot-free areas would create harm in total output value (direct, indirect, and induced) of $\$ 547$ million under low codling moth pressure; $\$ 557$ million under moderate codling moth pressure; and $\$ 510$ million under high codling moth pressure. Table 8 reports the potential losses faced by the industry under different rates of loss of apple maggotfree areas. Values have increased more than 10-fold when comparing estimates reported by Schotzko (1982) that ranged from $\$ 25$ million to $\$ 36$ million for the 1985 projected apple crop. Meanwhile, Zhao et al. (2007)

Table 7. Reduced output value of the Washington State apple industry, if $100 \%$ of the Washington apple-producing areas were apple maggot-threatened and -quarantined (100\% loss of apple maggot-free area). Reduced output value is presented for three scenarios assuming three levels codling moth pressure (low, moderate, and high) as of 2017.

\begin{tabular}{|c|c|c|c|}
\hline \multirow[b]{3}{*}{ Output value } & \multicolumn{3}{|c|}{ Reduced output value } \\
\hline & \multicolumn{3}{|c|}{ Levels of codling moth pressure } \\
\hline & Low & Moderate & High \\
\hline Direct effects ( $\$$ billion $)$ & 3.69 & 3.69 & 3.58 \\
\hline Indirect effects ( $\$$ billion) & 3.34 & 3.34 & 3.27 \\
\hline Induced effects ( $\$$ billion $)$ & 1.90 & 1.90 & 1.83 \\
\hline Total effects ( $\$$ billion $)$ & 8.92 & 8.92 & 8.68 \\
\hline $\begin{array}{l}\text { Losses in total output value } \\
\qquad(\$ \text { million })^{\mathrm{z}}\end{array}$ & -546.93 & -557.23 & -509.78 \\
\hline $\begin{array}{l}\text { Reduction relative to initial } \\
\text { apple industry value (\%) }\end{array}$ & -5.78 & -5.88 & -5.55 \\
\hline
\end{tabular}

estimated that the welfare loss for U.S. apple growers would amount $\$ 4$ million to $\$ 8$ million per year from increased spray costs if apple maggot infestation had spread at its historic rates.

\section{Summary and conclusions}

The 2016 PRA for apple maggot confirmed the risk of spreading the pest into pest-free areas with the movement of municipal green waste. In this study, we estimate the potential costs to the Washington economy of a potential spread of apple maggot to commercial apple-production areas. We estimate three major drivers for the additional costs and consequent economic impacts: additional chemical sprays, additional time in storage, and reduced output prices as a result of the extended storage period required for British Columbia and China.

When comparing the profits of apple operations in the three apple maggot-affected areas with the bestcase scenario [i.e., Area 4 (neither threatened nor quarantined)], we observe higher losses in profits for conventional apple orchards with low codling moth pressure relative to moderate and high codling moth pressure in apple maggot-affected Areas 1 and 2 and identical losses for organic apple orchards regardless of the level of pest pressure because the additional chemicals costs for apple maggot and storage costs are the same under low and moderate codling moth pest pressure.

The losses to the Washington apple industry's output value from

Table 8. Comparison of the losses in the contribution of the apple industry to the Washington State economy under different percentage losses in apple maggot-free areas $(20 \%, 40 \%, 60 \%, 80 \%$, or $100 \%)$ under three assumed levels of codling moth (CM) pressure as of 2017.

\begin{tabular}{|c|c|c|c|c|c|c|}
\hline Scenario & Baseline & $20 \% \mathrm{TQ}^{\mathrm{z}}$ & $40 \% \mathrm{TQ}$ & $60 \% \mathrm{TQ}$ & $80 \%$ TQ & $100 \% \mathrm{TQ}$ \\
\hline \multicolumn{7}{|l|}{ Low CM pressure } \\
\hline Output value ( $\$$ billion $)$ & 9.47 & 9.36 & 9.25 & 9.14 & 9.03 & 8.92 \\
\hline Reduction relative to baseline (\%) & & -1.12 & -2.28 & -3.45 & -4.61 & -5.78 \\
\hline \multicolumn{7}{|l|}{ Moderate CM pressure } \\
\hline Output value ( $\$$ billion $)$ & 9.48 & 9.37 & 9.26 & 9.15 & 9.03 & 8.92 \\
\hline \multicolumn{7}{|l|}{ High CM pressure } \\
\hline Output value ( $\$$ billion $)$ & 9.19 & 9.09 & 8.99 & 8.88 & 8.78 & 8.68 \\
\hline Reduction relative to baseline ( $\$$ /billion) & & -0.10 & -0.20 & -0.30 & -0.41 & -0.51 \\
\hline Reduction relative to baseline (\%) & & -1.07 & -2.19 & -3.31 & -4.43 & -5.55 \\
\hline
\end{tabular}

${ }^{\mathrm{z}} \mathrm{TQ}=$ increment in apple maggot-threatened and quarantine areas. 
a further spread of apple maggot infestation to the entire apple-production region are estimated to be $\$ 547$ million under low codling moth pressure, $\$ 557$ million under moderate pressure, and $\$ 510$ million under high pressure compared with their initial total output values. The magnitude of the impact of apple maggot infestation on the Washington economy depends on the proportion of the apple-production area affected. Changes in the Washington apple industry's total output value considering $20 \%, 40 \%, 60 \%$, and $80 \%$ of the production region that are both apple maggot threatened and quarantined at different levels of pest pressure are less than the changes in the output value if $100 \%$ of all apple-production region were threatened and quarantined. The main reason is that instead of only some portions of conventional and organic apple acreages incurring additional chemical costs for apple maggot, storage costs, apple pest certification fee, and price discounts, $100 \%$ of all apple acreage will incur all these additional costs to meet the requirements of exporting to British Columbia and China.

Given the negative economic impacts for Washington State, these analyses show evidence of the importance to the state's economy of an efficient pest control. Those costs shall be put in perspective when considering the need of seeking for alternative places to dispose municipal green waste, especially in the surroundings of increasingly populating metropolitan centers. The disposition of waste needs to be done in a way that would not foster the spread of pests. For example, the PRA by Sansford et al. (2016) suggests that municipal waste should be heat-treated before being transported from an apple maggot quarantine- to an apple maggot-free area, otherwise there would be a moderate risk of spreading the pest. Treating the waste adds additional costs for waste-management companies; however, spreading the pest could represent a much larger cost to the state's economy. Further, given that apple maggot is native to North America, it is possible that other current apple export destinations could adjust their access requirements to mirror those in place in China and British Columbia, further increasing potential losses.

\section{Literature cited}

Armah, P., J. Wimberly, G. Phillips, A. Pagan, and A. McVey. 2016. Diversification into specialty crops production as a regional economic development strategy for northeast Arkansas: An economic impact analysis. J. Food Distrib. Res. 47:36-44.

Bess, R. and Z.O. Ambargis. 2011. Inputoutput models for impact analysis: Suggestions for practitioners using RIMS II multipliers. Bur. Econ. Anal. Working Paper WP2012-3.

Board of Governors of the Federal Reserve System. 2017. Selected interest rates: Federal funds effective rate. 15 May 2017. <http://www.federalreserve.gov/ datadownload/Choose.aspx?rel=H15>.

Brunner, J. 2016. Scenarios for programs that are compatible for control of codling moth, leafroller and apple maggot. Washington State Univ. Tree Fruit Res. Ctr., Wenatchee.

Brunner, J. 2018a. Codling moth. 15 Aug. 2018. <http://treefruit.wsu.edu/ crop-protection/opm/codling-moth/>.

Brunner, J. 2018b. Apple maggot control options for WA apple growers. 15 Aug. 2018. <http://treefruit.wsu.edu/cropprotection/opm/am-control_waapplegrowers $/>$.

Brunner, J. and M. Klaus. 1993. Orchard pest management online apple maggot. 15 Aug. 2018. <http://jenny.tfrec.wsu. edu/opm/displaySpecies.php?pn=140>.

Collart, A.J., K. Hood, and J. Barnes. 2015. Overview and economic impact of the Mississippi blueberry industry. J. Food Distrib. Res. 46:63-64.

Courtney, R. 2016. Assessment analyzes risk for spread of apple maggot. $26 \mathrm{Apr}$. 2018. <http://www.goodfruit.com/ assessment-analyzes-risk-for-spread-ofapple-maggot $/>$.

Evans, E.A., J. Crane, A. Hodges, and J.L. Osborne. 2010. Potential economic impact of laurel wilt disease on the Florida avocado industry. HortTechnology 20:234-238.

Galinato, S. and R.K. Gallardo. 2012. 2011 cost estimates of establishing, producing, and packing Honeycrisp apples in Washington. Washington State Univ. Ext. Factsheet FS062E.

Galinato, S. and R.K. Gallardo. 2016. 2015 cost estimates of establishing, producing and packing Fuji apples in Washington. Washington State Univ. Ext. Factsheet TB29E.

Galinato, S., R.K. Gallardo, and Y. Hong. 2016a. 2014 cost estimates of establish- ing, producing and packing Gala apples in Washington. Washington State Univ. Ext. Factsheet TB18E.

Galinato, S., R.K. Gallardo, and Y. Hong. 2016b. 2014 cost estimates of establishing, producing and packing organic Gala apples in Washington. Washington State Univ. Ext. Factsheet TB19E.

Galinato, S., R.K. Gallardo, and Y. Hong. 2016c. 2014 cost estimates of establishing, producing and packing organic Red Delicious apples in Washington. Washington State Univ. Ext. Factsheet TB12E.

Gallardo, R.K. and S. Galinato. 2016. 2014 cost estimates of establishing, producing, and packing Red Delicious apples in Washington. Washington State Univ. Ext. Factsheet TB07E.

Hughes, D.W. 2003. Policy uses of economic multiplier and impact analysis. Choices 18(1):25-30.

IMPLAN. 2016. IMPLAN Pro: Washington state totals, 2015. 18 Sept. 2018. <http://shop.implan.com/state-leveldata>.

Kennedy, P. 1998. A guide to econometrics. 4th ed. MIT Press, Cambridge, MA.

Kirby, E. and D. Granatstein. 2018. Recent trends in certified organic tree fruit in Washington state: 2017. Washington State Univ. Ctr. Sustaining Agr. Natural Resources Org. Ser. 15 June 2017. <http://tfrec.cahnrs.wsu.edu/organicag/ wp-content/uploads/sites/9/2018/04/ WA_OrgtreeFruit_ann_rev_2017.pdf $>$.

Mon, P.N. and D.W. Holland. 2006. Organic apple production in Washington state: An input-output analysis. Renew. Agric. Food Syst. 21:134-141.

Nicholson, W. and C. Snyder. 2010. Intermediate microeconomics and its application. 11th ed. South-Western Cengage Learning, Mason, $\mathrm{OH}$.

Northwest Horticultural Council. 2018. Export manual individual countries. 15 Aug. 2018. <http://nwhort.org/exportmanual/countries-toc/ $>$.

Pendell, D.L., J. Leatherman, T.C. Schroeder, and G.S. Alward. 2007. The economic impacts of a foot-and-mouth disease outbreak: A regional analysis. J. Agric. Appl. Econ. 39:19-33.

Rose, A. and S. Liao. 2005. Modeling regional economic resilience to disasters: A computable general equilibrium analysis of water service disruptions. J. Reg. Sci. 45:75-112.

Sansford, C.E., V. Mastro, and J.R. Reynolds. 2016. Pest risk analysis (PRA) for apple 
maggot (Rhagoletis pomonella) moving on municipal green waste into the pest-free area (PFA) of the state of Washington, USA. 26 Apr. 2018. <http://agr.wa.gov/ plantsinsects/insectpests/applemaggot/>.

Schotzko, T. 1982. Estimated economic impact of apple maggot. Washington State Univ. Ext. Bul. 1132.

Seetin, M. 2017. U.S. apple crop outlook and overview. 15 Aug. 2018. <http:// usapple.org/wp-content/uploads / 2017/08/MarkSeetin.pdf>.

StataCorp. 2017. Stata statistical software: Release 15. StataCorp, College Station, TX.

U.S. Department of Agriculture. 2017a. Noncitrus fruits and nuts 2016 summary. 15 Apr. 2018. <http://usda.mannlib. cornell.edu/MannUsda/viewDocumentInfo. do?documentID $=1113>$.

U.S. Department of Agriculture. 2017b. Survey: Economics - Prices paid. 21 May 2017. <http://quickstats.nass.usda.gov/>.

Washington State Legislature. 2015. WAC 16-470-103. Establishing quarantines for apple maggot and plum curculio definitions. 15 Aug. 2018. <http://apps. leg.wa.gov $/$ wac $/$ default aspx? cite $=16$ 470-103>.
Washington State Legislature. 2018. WAC 16-390. Fruit and vegetable inspection districts, inspection fees, and other charges. 15 Aug. 2018. <http:// leg.wa.gov/CodeReviser/WACArchive/ Documents /2013/WAC-16-390CHAPTER.pdf $>$.

University of Wisconsin. 2018. Research on the economic impact of cooperatives IMPLAN methodology. 19 July 2018. <http://reic.uwcc.wisc.edu/implan/>.

Washington State Department of Agriculture. 2017. Apple maggot. 26 Apr. 2018. <https://agr.wa.gov/plantsinsects/ insectpests/applemaggot/ $>$.

Washington State Tree Fruit Association. 2016a. Monthly price data of conventional apples, 2011-12 and 2015-16 marketing periods. Washington State Tree Fruit Assn., Yakima.

Washington State Tree Fruit Association. 2016b. Annual crop summary, various years. Washington State Tree Fruit Assn., Yakima.
Washington State University. 2018. Crop protection guide for tree fruits in Washington apple programs. Washington State Univ. Ext. EB0419.

Winfree, J.A., J.J. McCluskey, R.C. Mittelhammer, and P. Gutman. 2004. Seasonal oligopoly power in the D'Anjou pear industry. J. Food Distrib. Res. 35: 56-65.

Zapata, S.D., R. Dudensing, R. Villanueva, D. Sekula, and G. Esparza-Diaz. 2016. Economic impact of the sugarcane aphid outbreak in Texas. Agr. Appl. Econ. Assn. Annu. Mtg., Boston, MA, 31 July-2 Aug. 2016.

Zhao, N., T. Huanwen, and L. Xiaona. 2006. Research on non-linear inputoutput model based on production function theory and a new method to update IO coefficients matrix. Appl. Math. Comput. 181:478-486.

Zhao, Z., T. Wahl, and T. Marsh. 2007. Economic effects of mitigating apple maggot spread. Can. J. Agr. Econ. 55: 499-514. 
Supplemental Table 1. Partial budgets for apples produced in threatened and quarantined area (Area 1), given different pestmanagement strategies under low, moderate, and high codling moth pressure, Washington State.

\begin{tabular}{|c|c|c|c|c|c|}
\hline & \multicolumn{5}{|c|}{ Control cost $(\$ / \text { acre })^{\mathrm{z}}$} \\
\hline & Red Delicious & Gala & Fuji & $\begin{array}{c}\text { Organic Red } \\
\text { Delicious }\end{array}$ & Organic Gala \\
\hline \multicolumn{6}{|c|}{ Low codling moth pressure } \\
\hline Additional returns & - & - & - & - & - \\
\hline Reduced costs & - & - & - & - & - \\
\hline \multicolumn{6}{|l|}{ Additional costs } \\
\hline Chemicals for $\mathrm{AM}^{\mathrm{y}}$ & 370.46 & 257.50 & 396.53 & 111.19 & 111.19 \\
\hline Storage $\operatorname{cost}^{x}$ & 0.84 & 1.21 & 1.23 & 0.75 & 1.14 \\
\hline Otherw & 33.19 & 23.12 & 35.55 & 10.00 & 10.04 \\
\hline Amort. estab. $\operatorname{cost}^{\mathrm{v}}$ & 91.50 & 86.59 & 133.24 & 27.57 & 37.60 \\
\hline Reduced returns ${ }^{\mathrm{u}}$ & 0.57 & 1.09 & 1.88 & 0.79 & 1.52 \\
\hline Net change in profit ${ }^{\mathrm{t}}$ & -496.56 & -369.51 & -568.43 & -150.30 & -161.49 \\
\hline Baseline profit (no AM) & 715.95 & $3,824.54$ & $4,631.84$ & $10,023.39$ & $13,159.58$ \\
\hline Profit given AM & 219.38 & $3,455.03$ & $4,063.41$ & $9,873.09$ & $12,998.08$ \\
\hline \multicolumn{6}{|c|}{ Moderate codling moth pressure } \\
\hline Additional returns & - & - & - & - & - \\
\hline Reduced costs & - & - & - & - & - \\
\hline \multicolumn{6}{|l|}{ Additional costs } \\
\hline Chemicals for AM & 199.91 & 86.92 & 225.97 & 111.19 & 111.19 \\
\hline Storage cost & 0.84 & 1.21 & 1.23 & 0.75 & 1.14 \\
\hline Other & 17.94 & 7.88 & 20.31 & 10.00 & 10.04 \\
\hline Amort. estab. cost & 49.45 & 29.48 & 76.13 & 27.57 & 37.60 \\
\hline Reduced returns & 0.57 & 1.09 & 1.88 & 0.79 & 1.52 \\
\hline Net change in profit & -268.71 & -126.58 & -325.52 & -150.30 & -161.49 \\
\hline Baseline profit (no AM) & 471.42 & $3,563.86$ & $4,371.16$ & $9,796.37$ & $13,038.57$ \\
\hline Profit given AM & 202.71 & $3,437.28$ & $4,045.63$ & $9,646.07$ & $12,877.08$ \\
\hline \multicolumn{6}{|c|}{ High codling moth pressure } \\
\hline Additional returns & - & - & - & & \\
\hline Reduced costs & - & - & - & & \\
\hline \multicolumn{6}{|l|}{ Additional costs } \\
\hline Chemicals for AM & 0.00 & 0.00 & 26.07 & & \\
\hline Storage cost & 0.84 & 1.21 & 1.23 & & \\
\hline Other & 0.08 & 0.11 & 2.44 & & \\
\hline Amort. estab. cost & 0.15 & 0.37 & 9.19 & & \\
\hline Reduced returns & 0.57 & 1.09 & 1.88 & & \\
\hline Net change in profit & -1.64 & -2.78 & -40.81 & & \\
\hline Baseline profit (no AM) & 145.63 & $3,330.60$ & $4,023.85$ & & \\
\hline Profit given high $\mathrm{AM}^{\mathrm{s}}$ & 143.99 & $3,327.82$ & $3,983.05$ & & \\
\hline
\end{tabular}

${ }^{\mathrm{z}} \$ 1 /$ acre $=\$ 2.4711 /$ ha

${ }^{\mathrm{y}}$ Cost of chemicals (materials and application) to control apple maggot (AM).

${ }^{\mathrm{x}}$ Cost of cold storage for an additional $40 \mathrm{~d}$ (common storage).

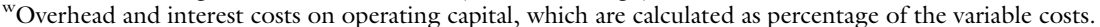

${ }^{\mathrm{v}}$ Amortized establishment costs represent the costs incurred during the establishment years (minus revenues during those years) that must be recaptured during the full production years.

${ }^{\text {u}}$ Due to decline in price received for the fruit brought about by putting the fruit in cold storage for an additional $40 \mathrm{~d}$.

${ }^{t}$ Net change in profit $=$ additional returns + reduced costs - additional costs - reduced returns.

${ }^{\mathrm{s}}$ Represents losses due to AM relative to the baseline. In other words, it shows the difference between baseline profit (no AM) and profit given AM. 
Research Reports

Supplemental Table 2. Partial budgets for apples produced in threatened and nonquarantined area (Area 2), given different pest management strategies under low, moderate and high codling moth pressure, Washington State.

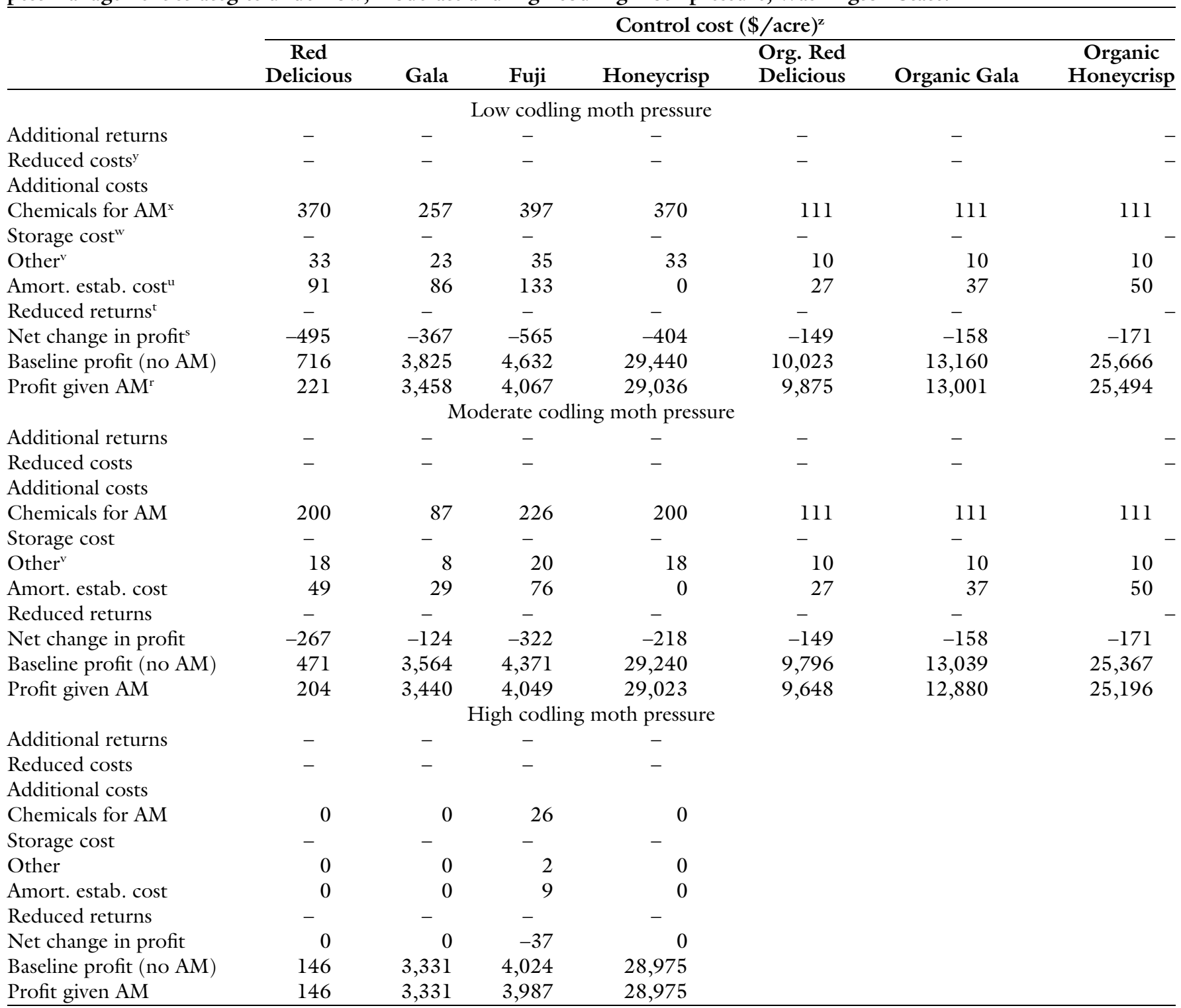

${ }^{\mathrm{z}} \$ 1 / \mathrm{acre}=\$ 2.471 \mathrm{l} / \mathrm{ha}$.

${ }^{\mathrm{y}}$ Reduction in organic certification fee. The fee is based on the gross return, and since the gross return in the scenario is lower, the fee is also lower

${ }^{x}$ Cost of chemicals (materials and application) to control apple maggot (AM).

wNo storage costs in Area 2.

voverhead and interest costs on operating capital, which are calculated as percentage of the variable costs.

"Amortized establishment costs represent the costs incurred during the establishment years (minus revenues during those years) that must be recaptured during the full production year.

${ }^{\mathrm{t}}$ No price decline in Area 2

${ }^{\mathrm{s}} \mathrm{Net}$ change in profit $=$ additional returns + reduced costs - additional costs - reduced returns.

${ }^{\mathrm{r}}$ Represents losses due to AM relative to the baseline. In other words, it shows the difference between baseline profit (no AM) and profit given AM. 
Supplemental Table 3. Partial budgets for apples produced in nonthreatened and quarantined area (Area 3), given different pest management strategies under low, moderate, and high codling moth pressure, Washington State.

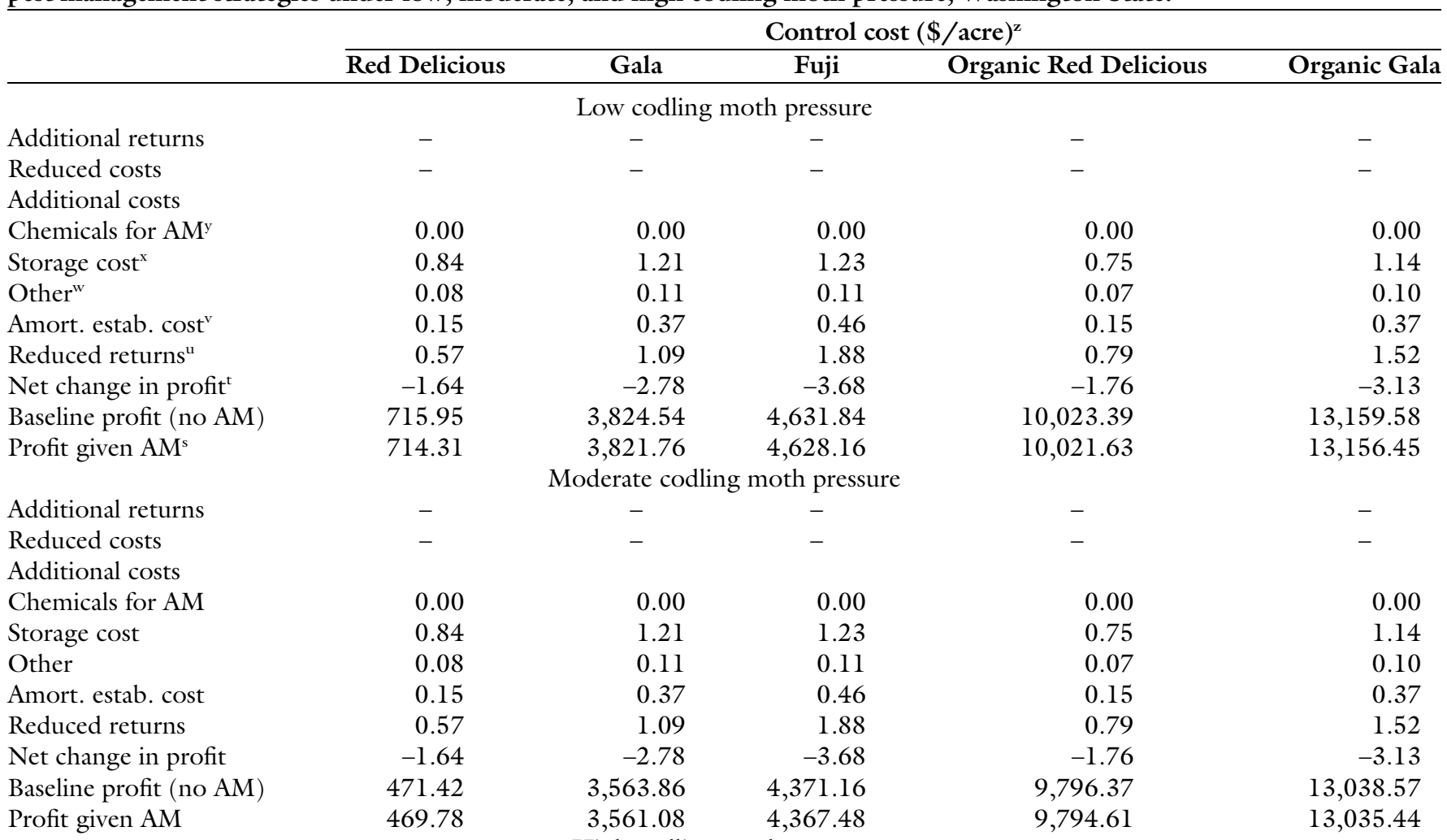

Additional returns

Reduced costs

Additional costs

Chemicals for AM

Storage cost

Other

$3,561.08 \quad 4,367.48$

$13,035.44$

Amort. estab. cost

Reduced returns

Net change in profit

Baseline profit (no AM)

High codling moth pressure

Profit given high AM

${ }^{\mathrm{z}} \$ 1 /$ acre $=\$ 2.4711 / \mathrm{ha}$.

${ }^{\mathrm{y}}$ Cost of chemicals (materials and application) to control apple maggot (AM).

${ }^{\mathrm{x}}$ Cost of cold storage for an additional $40 \mathrm{~d}$ (common storage).

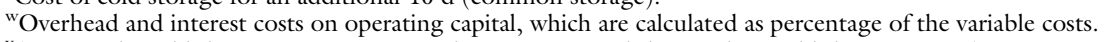

vAmortized establishment costs represent the costs incurred during the establishment years (minus revenues during those years) that must be recaptured during the full production years.

${ }^{u}$ Due to decline in price received for the fruit brought about by putting the fruit in cold storage for an additional $40 \mathrm{~d}$.

${ }^{t}$ Net change in profit $=$ additional returns + reduced costs - additional costs - reduced returns.

${ }^{\mathrm{s}}$ Represents losses due to AM relative to the baseline. In other words, it shows the difference between baseline profit (no AM) and profit given AM. 